\title{
EFFECTS OF CARBON BLACK CONTENT ON THE MICROSTRUCTURE AND PROPERTIES OF CARBON/CERAMIC CONDUCTIVE COMPOSITES
}

\author{
VPLIV ČRNEGA OGLJIKA NA MIKROSTRUKTURO IN \\ LASTNOSTI PREVODNIH KOMPOZITOV \\ OGLJIK/KERAMIKA
}

\author{
Xiao Gao ${ }^{1,2}$, Xin Zheng ${ }^{1,2}$, Juncheng Liu ${ }^{1,2 *}$, Shenqiu Zhai ${ }^{2,3}$, Guoliang Yuan ${ }^{4}$ \\ ${ }^{1}$ School of Materials Science and Engineering, Shandong University of Technology, Zibo 255049, China \\ ${ }^{2}$ National Engineering Research Center of Industrial Ceramics of China, 12 Zhangzhou Road, Zibo 255049, China \\ ${ }^{3}$ School of Mechanical Engineering, Shandong University of Technology, Zibo 255049, China \\ ${ }^{4}$ Shandong Electric Shield Polytron Technologies Inc, Zibo 255000, China \\ Prejem rokopisa - received: 2018-04-20; sprejem za objavo - accepted for publication: 2018-11-22
}

\author{
doi:10.17222/mit.2018.078
}

\begin{abstract}
Carbon/ceramic conductive composites have been widely used in many fields such as aerospace, industrial heating and health care due to the excellent characteristics of the ceramic matrix and carbon-based conductive fillers. In this paper, carbon/ceramic conductive composites were prepared with a ceramic matrix (albite, diopside and quartz) and carbon-black (CB) conductive filler, and the effects of the $\mathrm{CB}$ content on the phase composition, microstructure, sintering performance, mechanical and electrical properties of the composites were studied. The results showed that $\mathrm{CB}$ particles entered the pores among the ceramics particles when the CB content increased from $0 \mathrm{w} / \%$ to $5 \mathrm{w} / \%$, accompanied with a degradation of the porosity, water absorption, sintering performance and electrical conductivity but an enhancement of the mechanical properties. With a further increase in the $\mathrm{CB}$ content, the number of the $\mathrm{CB}$ particles on the surfaces of the ceramic particles was increased and the porosity began to increase while the mechanical properties were degraded. During the increase in the CB content, there was little variation in the sintering properties but the electronic conductivity decreased a lot.
\end{abstract}

Keywords: carbon/ceramic conductive composites, carbon black content, microstructure, properties

Kompoziti ogljik/keramika s keramično matrico in prevodnim polnilom se danes zaradi odličnih lastnosti uporabljajo na mnogih področjih, kot so letalske in vesoljske tehnologije, industrijsko ogrevanje in zdravstvo. Avtorji opisujejo pripravo prevodnih kompozitov s keramično matrico (albit, diopsid in kvarz) in prevodnim polnilom iz črnega ogljika (CB, angl:: carbon black). Raziskovali so vpliv vsebnosti $\mathrm{CB}$ na fazno sestavo, mikrostrukturo, sinterabilnost, mehanske in električne lastnosti izdelanih kompozitov. Rezultati preiskav so pokazali, da se CB delci nahajajo v porah med keramičnimi delci, ko vsebnost CB delcev naraste z 0 na 5 masnih deležev. To zmanjša poroznost, absorpcijo vode, sinterabilnost in električno prevodnost, a izboljša mehanske lastnosti kompozita. Z nadaljnjim povečevanjem vsebnosti CB se povečuje število CB delcev na površini keramičnih delcev, poroznost narašča in mehanske lastnosti se poslabšajo. S povečevanjem vsebnosti delcev se le malo spremeni sinterabilnost, elektronska prevodnost pa se močno zmanjša.

Ključne besede: prevodni kompoziti ogljik/keramika, vsebnost črnega ogljika, mikrostruktura, lastnosti

\section{INTRODUCTION}

As a new kind of functional material, a carbon/ceramic composite inherits excellent characteristics from the ceramic-matrix material and carbon-based conductive fillers. Such composites exhibit excellent electrical and infrared-radiation performances, and have been widely used in the fields of aerospace, ${ }^{1-3}$ industrial heating, ${ }^{4,5}$ health care, ${ }^{6-8}$ and others. At present, investigations on carbon/ceramic conductive composites mainly focus on the effects of the conductive-filler type and content on the performances of the composites. One of the most representative carbon-based conductive fillers is graphite. However, Duan et al. ${ }^{9}$ found that the mechanical and electrical properties of such composites are

*Corresponding author e-mail: jchliu@sdut.edu.cn significantly affected by the poor sintering performance of graphite.

Carbon black $(\mathrm{CB})$ is a natural semiconductor material. It is an abundant resource available at a low cost and has a volume resistivity in a range of $10^{-3}$ to $10 \Omega \cdot \mathrm{m}$, which can improve the electrical conductivity. At present, $\mathrm{CB}$ is commonly used in many fields. ${ }^{10}$ In a process of preparing polymer matrix composites with $\mathrm{CB}$ as the conductive filler, a small amount of CB can not only improve the strength of the composites but also adjust the electrical resistivity and improve the electrical conductivity. Liu et al. ${ }^{11}$ studied the effects of the CB content on silicone rubber composites. It was found that the $\mathrm{CB}$ content had a great effect on the electrical conductivity of rubber, leading to a decrease in its volume resistivity from $587 \Omega \mathrm{cm}$ to $165 \Omega \mathrm{cm}$. Wu et al. ${ }^{12}$ studied the effects of the $\mathrm{CB}$ content on the performance of silicone rubber-based force-sensitive composites and discovered 
that the tensile property of the composites could be improved when the CB content reached a certain value, inducing the maximum tensile strength of $3.5 \mathrm{MPa}$. However, the creep resistance and high-temperature resistance of polymer-matrix composites are lower than those of ceramic-matrix composites ${ }^{13}$ so that the applications of polymer-matrix composites are limited to some degree.

In this paper, carbon/ceramic conductive composites were prepared with ceramic as the matrix and $\mathrm{CB}$ as the conductive filler. The effects of the $\mathrm{CB}$ content on the phase composition, microstructure, sintering performance, mechanical and electrical properties of the composites were investigated and the conductive mechanism was discussed.

\section{EXPERIMENTAL PART}

\subsection{Preparation of carbon/ceramic conductive compo- sites}

Four samples of carbon/ceramic conductive composites were prepared, having a ceramic matrix (albite, diopside and quartz) and $\mathrm{CB}$, and their nominal compositions are shown in Table 1. The mixtures were milled, dried, granulated, dry-pressed and sintered at a low temperature. The forming pressure was $20 \mathrm{MPa}$ and the sintering temperature was $1120{ }^{\circ} \mathrm{C}$.

Table 1: Nominal compositions of different samples $(w / \%)$

\begin{tabular}{|c|c|c|c|}
\hline Sample code & Ceramic matrix & Carbon black & Balance \\
\hline a & 94 & 5 & 1 \\
\hline b & 89 & 10 & 1 \\
\hline c & 86 & 13 & 1 \\
\hline d & 83 & 16 & 1 \\
\hline
\end{tabular}

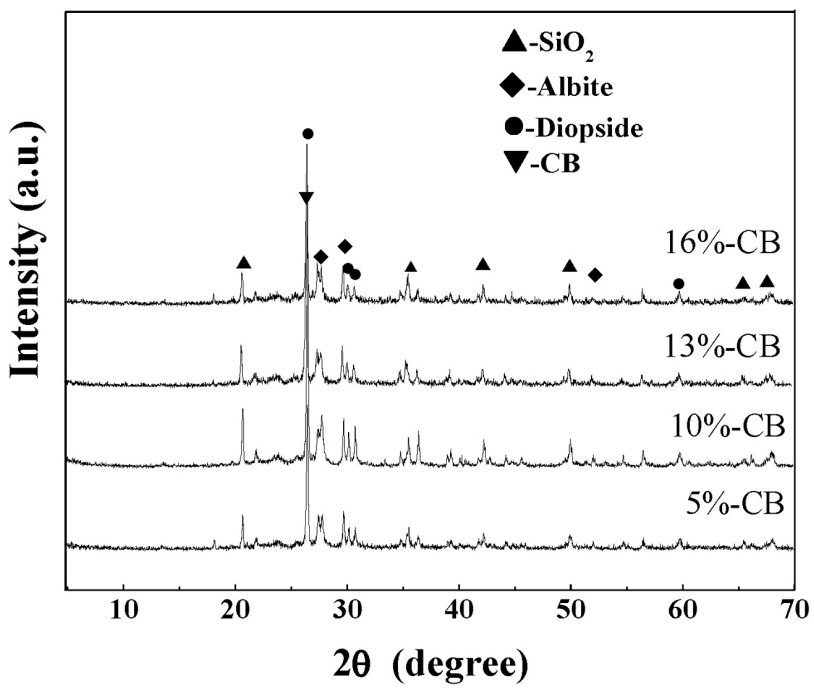

Figure 1: Effects of the CB content on the phase composition of the carbon/ceramic conductive composites

\subsection{Characterization and property test of carbon/cera- mic conductive composites}

The phase composition was identified using an X-ray diffractometer (XRD, D8 Advance, Brucker, Germany), with a scan angle range of $5-70^{\circ}$. The dispersivity and connectivity of the conductive filler within the composites were observed with a field-emission scanning electron microscope (FESEM, Sirion 2000, FEI, Netherlands). The porosity and water absorption of the composites were determined with the Archimedes method using distilled water as the liquid medium. Linear firing shrinkage was simply calculated by measuring the length of the specimens before and after the sintering. Weight loss was determined by measuring the weight of the specimens before and after the sintering. Bending strength was tested via a three-point bending test with a support distance of $30.0 \mathrm{~mm}$ and a cross-head speed of $0.50 \mathrm{~mm} / \mathrm{min}$. Electrical resistivity was measured using the four-probe method.

\section{RESULTS}

\subsection{Phase analysis}

Figure 1 shows the effects of the $\mathrm{CB}$ content on the phase composition of the prepared carbon/ceramic conductive composites. As can be seen, the diffraction patterns of the samples with $(5,10,13$ and 16) w/\% CB are basically the same, and all of them only display diffraction peaks corresponding to $\mathrm{CB}$, diopside, quartz and albite. These results show that no other new phases appear in the carbon/ceramic conductive composites with an increase in the $\mathrm{CB}$ content. ${ }^{14}$

\subsection{Microstructure and morphology analysis}

Figure 2 shows the effects of the $\mathrm{CB}$ content on the microstructure and morphology of the carbon/ceramic conductive composites. As shown in Figure 2a, CB particles are distributed uniformly in the pores of the ceramic particles when the $\mathrm{CB}$ content is $5 \mathrm{w} / \%$. A small amount of CB particles have been linked into a chain, but most of them are separated by ceramic particles. Hence, the composites with $5 w / \%$ CB exhibit a certain electrical conductivity, but the conductivity is poor. When the $\mathrm{CB}$ content is $10 w / \%$, as shown by Figure $\mathbf{2 b}$, CB particles begin to reunite and congeal. They are distributed at the interface of the ceramic particles and the filling, in the pores of ceramic particles. The average distance between $\mathrm{CB}$ particles decreases, and ceramic particles are in contact with each other. As a result, there are numerous conductive paths formed by $\mathrm{CB}$ within the conductive composite. ${ }^{15}$ With a further increase in the CB content, as shown in Figures $\mathbf{2 c}$ and $\mathbf{2 d}$, the pores of the ceramic particles are filled with the reuniting CB particles ${ }^{16}$ and the surfaces of the ceramic particles are covered by $\mathrm{CB}$ particles. Consequently, a layer is formed by CB particles and the connection among ceramic particles is 

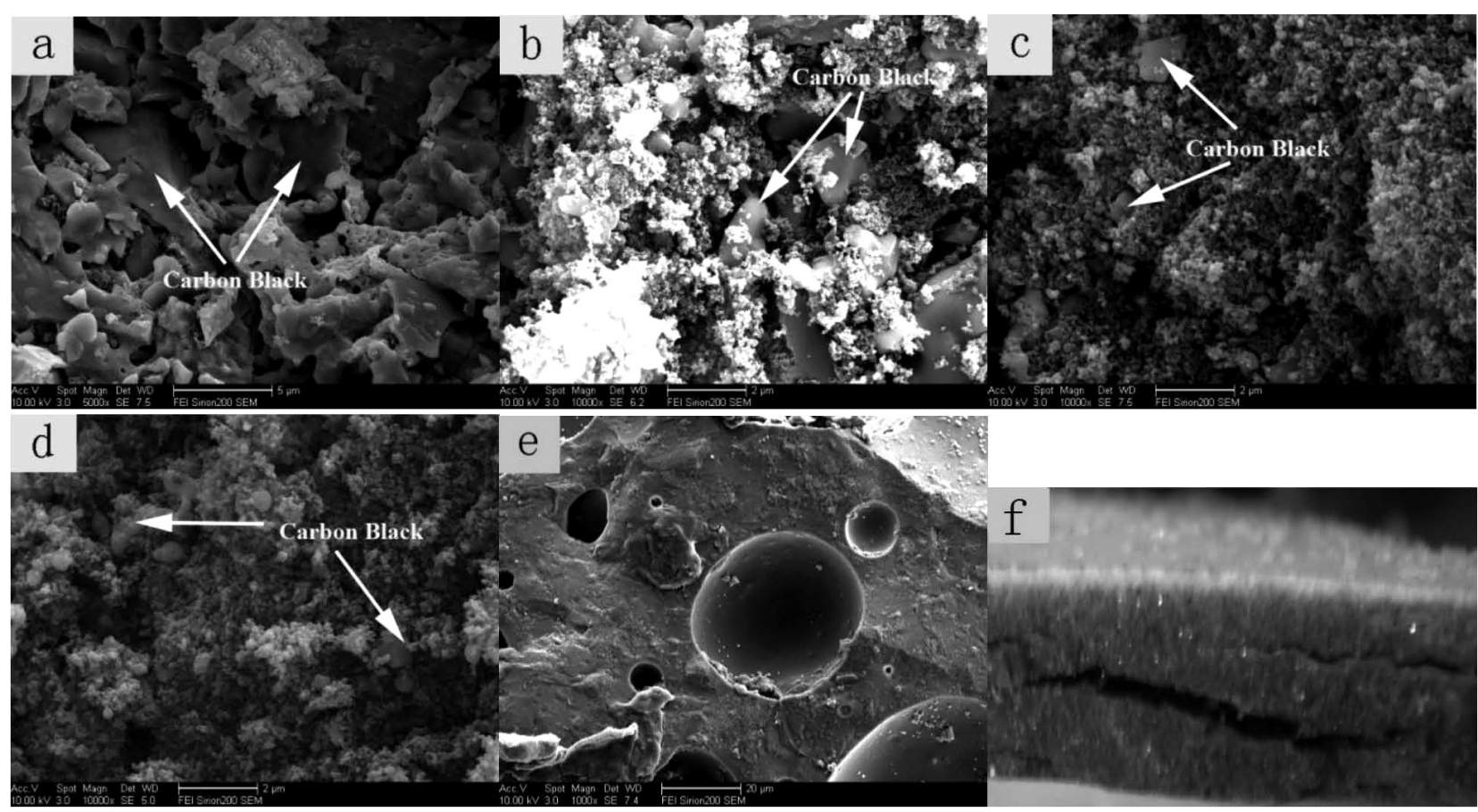

Figure 2: Effects of the $\mathrm{CB}$ content on the microstructure and morphology of the carbon/ceramic conductive composites a) $5 w / \%$, b) $10 w / \%$, c) $13 w / \%$, d) $16 w / \%$, e) $0 w / \%$, f) cracking of the sample with $13 w / \%$ CB after the sintering

broken. ${ }^{17}$ In addition, it can be seen that there is no difference between Figure 2c and Figure 2d except for an obvious crack in Figure 2c. This means that if the CB content is beyond a certain amount, the distances increase, thus leading to a decrease of the binding force.

\subsubsection{Effects of the CB content on the porosity and} water absorption of the carbon/ceramic conductive composites

Figure 3 shows the effects of the $\mathrm{CB}$ content on the porosity and water absorption of the carbon/ceramic conductive composites. As can be seen, when the $\mathrm{CB}$ content increases from $0 \mathrm{w} / \%$ to $5 \mathrm{w} / \%$, the porosity of the composites exhibits a decreasing trend; when the $\mathrm{CB}$ content exceeds $5 \mathrm{w} / \%$, the porosity begins to increase

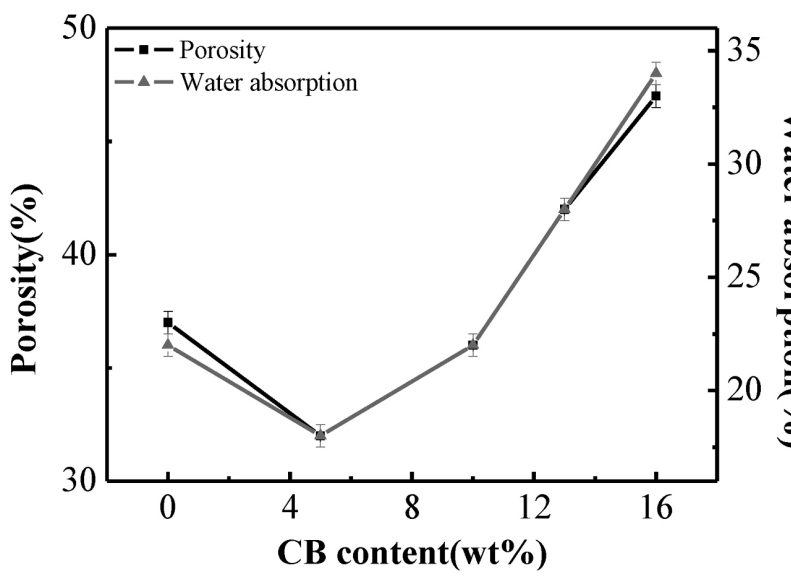

Figure 3: Effects of the $\mathrm{CB}$ content on the porosity and water absorption of the carbon/ceramic conductive composites with the $\mathrm{CB}$ content. When the $\mathrm{CB}$ content is low, the pores of the ceramic particles are filled with $\mathrm{CB}$ particles, decreasing the porosity of the composites. With an increase in the $\mathrm{CB}$ content, the number of pores within the composites decreases and large amounts of CB particles are distributed along the boundaries of the ceramic particles. Thus, the average distance between ceramic particles increases and the porosity becomes large. ${ }^{18}$

For the water absorption of the carbon/ceramic conductive composites, it can be seen from Figure 3 that it is positively correlated with the porosity.

\subsection{Effects of the $C B$ content on the sintering perfor- mance of the carbon/ceramic conductive compo- sites}

Figure 4 shows the effects of the $\mathrm{CB}$ content on the linear firing shrinkage rate and weight loss of the carbon/ceramics conductive composites. The linear firing shrinkage rate first decreases sharply to the lowest point of about $10 w / \% \mathrm{CB}$, and then increases slowly to a small extent. At the same time, the weight loss of the composites gradually increases when the $\mathrm{CB}$ content increases from $0 w / \%$ to $5 w / \%$, but hardly changes with the further increase of the $\mathrm{CB}$ content. When the $\mathrm{CB}$ content is low, the pores in the composites are filled with $\mathrm{CB}$ particles and the shrinkage of the ceramic particles is prevented by the $\mathrm{CB}$ particles. ${ }^{19}$ When the $\mathrm{CB}$ content exceeds $5 w / \%$, as shown in Figure 3, the CB particles are distributed on the surfaces of the ceramic particles, and the shrinkage of the ceramic particles continues to be prevented. The binding force among the ceramic 


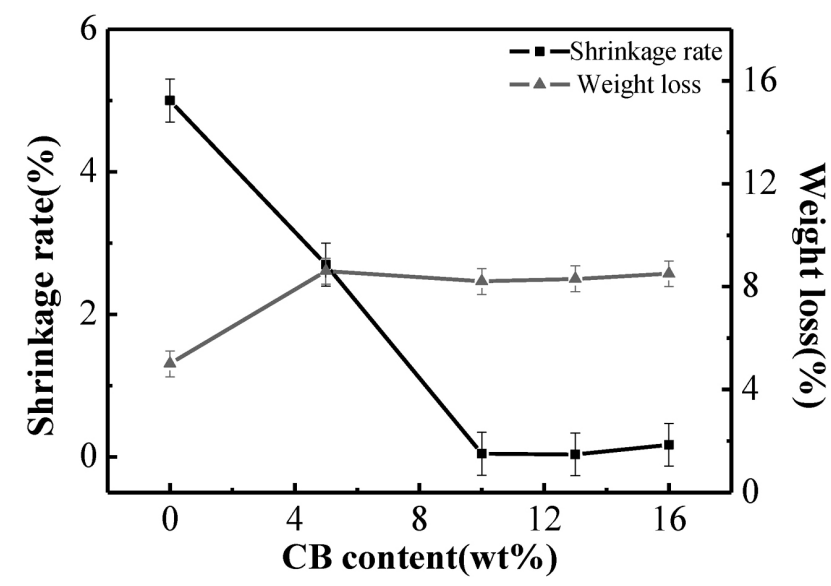

Figure 4: Effects of the $\mathrm{CB}$ content on the linear firing shrinkage rate and weight loss of the carbon/ceramic conductive composites

particles becomes smaller and smaller, and it finally vanishes. Consequently, some cracks appear in the composites (Figure 2f). On the other hand, the weight loss of the ceramic matrix is mainly caused by the dehydration effect during the sintering process when the $\mathrm{CB}$ content is $0 w / \%$. At a sintering temperature lower than $400{ }^{\circ} \mathrm{C}$, hygroscopic water and free water in a ceramic body are discharged. Later, constitutional water is discharged when the temperature is above $400{ }^{\circ} \mathrm{C}$ but below $600{ }^{\circ} \mathrm{C}$. With a further increase in the sintering temperature, the dehydration speed slows down and the discharge of the residual water is almost stopped in a temperature range of $800-1000{ }^{\circ} \mathrm{C}$. Because of this dehydration effect, a weight loss of a ceramic material without carbon appears during the sintering process. ${ }^{20}$ When $\mathrm{CB}$ particles are added, the following chemical reactions occur:

$$
\begin{aligned}
2 \mathrm{C}+\mathrm{O}_{2} & \rightarrow 2 \mathrm{CO} \\
\mathrm{C}+\mathrm{H}_{2} \mathrm{O} & \rightarrow \mathrm{CO}+\mathrm{H}_{2}
\end{aligned}
$$

Regarding the above reactions, the carbon within the body can react with oxygen and water vapor to produce $\mathrm{CO}$ and $\mathrm{H}_{2}$. $\mathrm{CO}$ and $\mathrm{H}_{2}$ flow from the body as gaseous products, which can increase the weight loss. With the increasing $\mathrm{CB}$ content, the amount of the oxygen within the body becomes smaller and smaller, and it totally runs out when the CB content increases to $5 w / \%$. Because of the low sintering temperature and fast-speed firing, there is no time for carbon to react with the oxygen from the outside so the weight loss of the composites shows no obvious change with a further increase of the $5 w / \% \mathrm{CB}$ content.

\subsection{Effects of the CB content on the mechanical and electrical properties of the carbon/ceramic conduc- tive composites}

Figure 5 shows the effects of the CB content on the bending strength and resistivity of the carbon/ceramic conductive composites. The bending strength first increases and then decreases. To be specific, the bending strength increases from 25.3 MPa to $30.0 \mathrm{MPa}$ when the $\mathrm{CB}$ content increases from $0 \mathrm{w} / \%$ to $5 \mathrm{w} / \%$ and then begins to decrease with a further increase in the $\mathrm{CB}$ content. It is noticed that the bending strength of the composites is closely related to the porosity:

$$
\sigma=\sigma_{0} e^{-k \alpha}
$$

where $\sigma$ is the bending strength of a material with a certain porosity, $\sigma_{0}$ is the bending strength of a material without porosity, $\alpha$ is the porosity and $\mathrm{k}$ is the constant. Equation (3) indicates that there is an exponential relationship between the bending strength of the composites and the reciprocal number for porosity. That is to say, the bending strength of composites is directly affected by the porosity. The larger the porosity, the lower is the bending strength. From the viewpoint of mechanics, the porosity is equivalent to the internal constriction. It can reduce the effective sectional area of a material and lead to stress concentration, thus reducing the strength. When the $\mathrm{CB}$ content is $5 \mathrm{w} / \%$, there are a lot of sintered necks that result in a decrease in the porosity so that almost all particles are connected with each other to form a whole, which can induce a relatively high bending strength.

Based on the above analysis, it can be concluded that the residual porosity of ceramic materials can be reduced by adding an appropriate amount of $\mathrm{CB}$ and refining the crystalline grains, which modifies the material densification and improves their mechanical properties. However, if the $\mathrm{CB}$ content is excessive, the internal structure of a composite may be broken and the boundaries of ceramic particles become fuzzy. As a result, the connections between ceramic particles become loose, finally reducing the material compactness. ${ }^{21}$

On the other hand, with an increase in the CB content, the resistivity of the composites decreases sharply. When the CB content increases to $7 w / \%$, the resistivity enters the conductivity saturated zone where it remains relatively steady with the increasing $\mathrm{CB}$ content. This variation trend of the resistivity with the $\mathrm{CB}$ content can

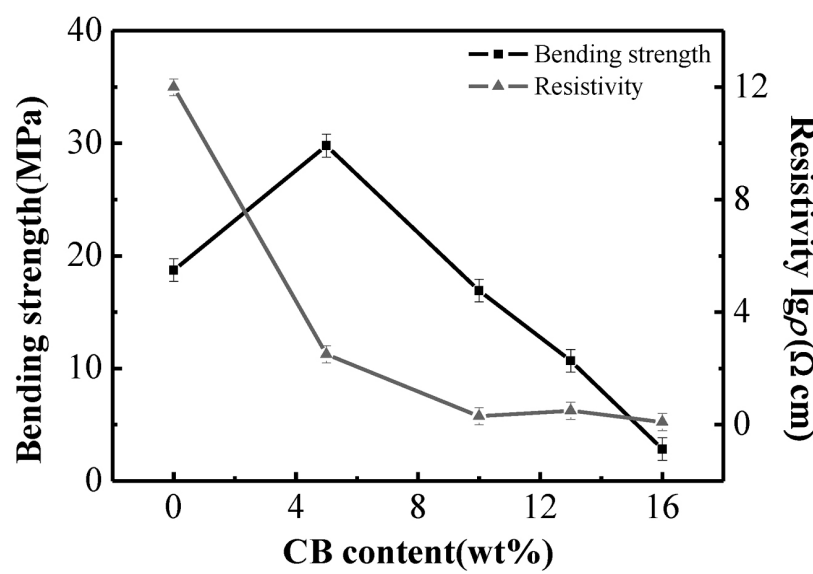

Figure 5: Effects of the $\mathrm{CB}$ content on the bending strength and resistivity of the carbon/ceramic conductive composites 
be explained with the infinite-network-chain theory. When the $\mathrm{CB}$ content is low, the $\mathrm{CB}$ particles are isolated or they exist as small collectives in the composites so that the resistivity is lower. ${ }^{22}$ With an increase in the $\mathrm{CB}$ content, the distances between the CB particles become smaller and there are a lot of conductive nets due to the particle overlapping. Thus, electrons can be conducted along the conductive nets formed by the CB particles and the resistivity mainly depends on the conductive ability of the $\mathrm{CB}$ particles. When the $\mathrm{CB}$ content continues to increase above $7 w / \%$, the number of conductive chains increases so that the resistivity of the composites decreases, but this trend slows down. ${ }^{23}$

As shown in Figure 5, the resistivity first increases and then decreases with the increase in the $\mathrm{CB}$ content after entering the saturated zone. This is mainly attributed to the initiation of cracks when the $\mathrm{CB}$ content increases to $13 w / \%$ (Figure 2f). The distances between the $\mathrm{CB}$ particles become larger and the resistivity increases accordingly. With a further increase in the $\mathrm{CB}$ content, the distances between the $\mathrm{CB}$ particles decrease and the resistivity also decreases slightly.

For comparison, Figure 6 presents the effects of the graphite content on the resistivity of the carbon/ceramic conductive composites. ${ }^{24}$ It can be seen that when the conductive-filler content is $5 \mathrm{w} / \%$, the resistivity of the composites filled with $\mathrm{CB}$ is $10^{3} \Omega \cdot \mathrm{cm}$, while that of the composites filled with graphite is $10^{7} \Omega \cdot \mathrm{cm}$. The results show that at the same conductive-filler amount, the resistivity of the composites prepared with $\mathrm{CB}$ is lower than that of the composites prepared with graphite. When the CB content is $7 w / \%$, the composites are in the conductivity saturated zone, and the resistivity varies little with the increasing $\mathrm{CB}$ content. ${ }^{5}$ By contrast, the composites do not enter the conductivity saturated zone until the graphite content reaches about $17.5 \mathrm{w} / \%$. This means that the percolation threshold of $\mathrm{CB}$ is much lower than that of graphite. ${ }^{25}$ Thus, doping CB is better

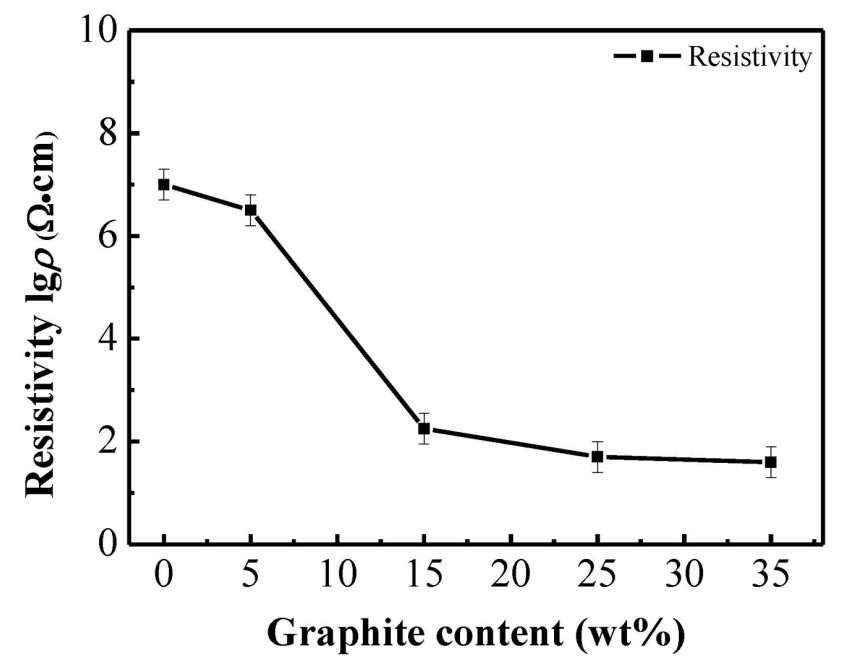

Figure 6: Effects of the graphite content on the resistivity of the carbon/ceramic conductive composites than doping graphite when preparing conductive composites with a certain resistivity.

\section{CONCLUSIONS}

In summary, carbon/ceramic conductive composites were prepared with a ceramic matrix and $\mathrm{CB}$ conductive filler, and the effects of the $\mathrm{CB}$ content on the microstructure, sintering performance, mechanical and electrical properties were investigated. The following conclusions can be drawn:

1) When the CB content increases from $0 w / \%$ to $5 w / \%$, the porosity and water absorption of the composites gradually decrease to the lowest points of $32 \%$ and $18 \%$, respectively. With a further increase in the CB content, both the porosity and water absorption show an increasing trend.

2) When the $\mathrm{CB}$ content increases from $0 w / \%$ to $10 w / \%$, the linear firing shrinkage rate of the composites decreases sharply and reaches the lowest point when the CB content is $10 w / \%$. With a further increase in the $\mathrm{CB}$ content, the linear firing shrinkage rate increases slowly and changes little. On the other hand, when the CB content increases from $0 \mathrm{w} / \%$ to $5 \mathrm{w} / \%$, the weight loss of the composites increases gradually and reaches the highest point when the $\mathrm{CB}$ content is 5 w/\%. A further increase in the $\mathrm{CB}$ content has no significant effect on the weight loss.

3) When the CB content increases from $0 w / \%$ to $5 w / \%$, the bending strength of the composites increases from 25.3 $\mathrm{MPa}$ to $30.0 \mathrm{MPa}$ and reaches the highest point when the CB content is $5 w / \%$. A further increase in the $\mathrm{CB}$ content results in a gradual decrease in the bending strength. On the other hand, when the $\mathrm{CB}$ content increases from $0 \mathrm{w} / \%$ to $10 \mathrm{w} / \%$, the resistivity of the composites decreases significantly, but a further increase in the $\mathrm{CB}$ content has no significant effect on the resistivity.

\section{Acknowledgment}

This work was financially supported by the Shandong Province science and technology major special project, Grant no. 2015ZDXX0402C05, and by University-City Cooperation Project of Zibo, Grant no. 2016ZBXC172.

\section{REFERENCES}

${ }^{1}$ Z. G. Zhang, Functional Composites, $1^{\text {nd }}$ ed., Chemical Industry Press, Beijing 2004, 108

${ }^{2}$ H. Q. Ru, L. Yu, L. Zuo, X. X. Xue, X. D. Sun, Carbon/ceramic heat-resistant composite material and preparation process thereof, China Patent: CN200510047738.4, (2006)

${ }^{3}$ R. Kumar, A. Kumar, M. Kaur, Influence of coal tar pitch coating on the properties of micro and nano $\mathrm{SiC}$ incorporated carbon-ceramic composites, J. Mater. Sci., 44 (2009) 17, 4633-4638, doi:10.1007/s10853-009-3707-1

${ }^{4}$ Y. Zheng, Carbon/ceramic composite material preparation method, China Patent: CN201210372467.X, (2014) 
${ }^{5}$ Y. Li, J. T. Xia, H. M. Shao, X. F. Lu, Study on electric heating property of carbon/ceramic composites, J. Aeronaut. Mater., 26 (2006) 2, 57-61 doi:10.3969/j.issn.1005-5053.2006.02.014

${ }^{6}$ L. M. Manocha, P. Guddu, S. Manocha, Carbon-ceramic composites for friction applications, Mechanics of Mech. Adv. Mater. Struct., 21 (2014) 3, 172-180, doi:10.1080/15376494.2013.834095

${ }^{7}$ J. C. Liu, Conductive Infrared Radiation Substrate Bath Room China Patent: CN200620160962.4, (2007)

${ }^{8} \mathrm{~S}$. L. Li, Infrared electric heating ceramic tile/ceramic plate, China Patent: CN20520081152.5, (2006)

${ }^{9}$ X. D. Duan, Y. Z. Xie, The influence of graphite content on the sintering of carbon/ceramic conductive composite, Ceram. Stud. J., 16 (2001) 2, 1-4, doi:10.3969/j.issn.1000-9892.2001.02.001

${ }^{10} \mathrm{X}$. Huang, Study on conductivity of carbon-black-filled plastics and its application, Plast. Sci. Technol., (2001) 3, 4-8 doi:10.3969/j.issn. 1005-3360.2001.03.002

${ }^{11}$ X. Y. Liu, C. Chen, Y. Y. Yang, Preparation and performance of silicone rubber composite filled with carbon black, Insul. Mater., 45 (2012) 1, 15-18 doi:10.3969/j.issn.1009-9239.2012.01.005

${ }^{12}$ J. Y. Wu, Y. H. Huang, J. Guo, K. Zhang, Z. Y. Yi, Effect of addition level of carbon black on properties of force-sensitive composite based on silicone rubber, China Rubber Ind., 59 (2012) 5, 276-281, doi:10.3969/j.issn.1000-890X.2012.05.004

${ }^{13}$ X. L. Shang, C. Jiang, J. W. Zhang, S. Ju, D. Z. Jiang, Effects of nano-fillers on creep behavior of polymers and their composites, Polym. Mater. Sci. Eng., 32 (2016) 7, 184-190 doi:10.16865/j.cnki. 1000-7555.2016.07.034

${ }^{14}$ Q. S. Li, Y. J. Zhang, H. B. Sun, Y. X. Zhai, C. He, Effect of carbon black content and molding pressure on the thermal conductivity of $\mathrm{SiC} / \mathrm{Si}$ ceramic composites, Key Eng. Mater., 655 (2015) 58, 58-61, doi:10.4028/www.scientific.net/kem.655.58

${ }^{15}$ G. F. Lin, B. Huang, X. R. Chen, Y. Q. Liao, L. R. Tang, Q. L. Zeng, Preparation and characterization of carbon/pottery composite with physical method, Sci. Silvae Sin., 46 (2010) 12, 125-129, doi:10.11707/j.1001-7488.20101221

${ }^{16}$ Y. H. Liu, L. Ma, M. S. Liu, Effects of the addition of carbon black on structure and properties of insulating material in the system of
$\mathrm{MgO}-\mathrm{Al}_{2} \mathrm{O}_{3}-\mathrm{SiO}_{2}$, Bull. Chin. Ceram. Soc., 29 (2010) 3, 689-691, doi:10.16552/j.cnki.issn1001-1625.2010.03.014

${ }^{17}$ W. Wei, J. T. Xia, J. Li, J. L. Zhao, Q. C. Zhao, Y. Z. Li, F. L. Liu, Research on electric heating property of new carbon/ceramic composite, J. Funct. Mater., 9 (2011) 42, 1619-1626

${ }^{18}$ F. Chen, F. Cao, H. L. Pan, K. Y. Wang, Q. Shen, J. L. Li, S. Q. Wang, Mechanical and dielectric properties of silicon nitride ceramics with high and hierarchical porosity, Mater. Des., 40 (2012), 562-566, doi:10.1016/j.matdes.2012.03.026

${ }^{19}$ S. H. Chiu, S. T. Wicaksono, K. T. Chen, C. Y. Chen, Mechanical and thermal properties of photopolymer/CB (carbon black) nanocomposite for rapid prototyping, Rapid Prototyping J., 21 (2015) 3, 262-269, doi:10.1108/rpj-11-2011-0124

${ }^{20}$ K. S. Kim, S. J. Park, Electrochemical performance of activated carbons $/ \mathrm{Mn}_{3} \mathrm{O}_{4}$-carbon blacks for supercapacitor electrodes, Bull. Korean Chem. Soc., 34 (2013) 8, 2343-2347, doi:10.5012/bkcs. 2013.34.8.2343

${ }^{21}$ Q. C. Ling, J. Z. Sun, Q. Zhao, Q. Y. Zhou, Effects of carbon black content on microwave absorbing and mechanical properties of linear low density polyethylene/ethylene-octene copolymer/ calcium carbonate composites, Polym.-Plast. Technol. Eng., 50 (2011) 50, 89-94, doi:10.1080/03602559.2010.531416

${ }^{22}$ P. L. Cong, P. J. Xu, S. F. Chen, Effects of carbon black on the antiaging, rheological and conductive properties of SBS/asphalt/carbon black composites, Constr. Build. Mater., 52 (2014) 2, 306-313, doi:10.1016/j.conbuildmat.2013.11.061

${ }^{23}$ N. Stübler, J. Fritzsche, M. Klueppel, Mechanical and electrical analysis of carbon black networking in elastomers under strain, Polym. Eng. Sci., 51 (2011) 6, 1206-1217, doi:10.1002/pen.21888

${ }^{24}$ X. Zheng, J. C. Liu, J. H. Bai, Z. K. Fan, Preparation and properties of graphite/ceramic conductive composites, Acta Mater. Compositae Sin., 26 (2009) 4, 107-110, doi:10.13801/j.cnki.fhclxb.2009.04.033

${ }^{25}$ X. W. Wu, G. X. Du, M. H. Fang, L. F. Mei, Microstructure and electrical resistivity of carbon/carbon composites prepared by thermal gradient chemical vapor infiltration, J. Reinf. Plast. Compos., 31 (2012) 31, 837-844, doi:10.1177/0731684412447865 